\title{
Brown-midrib genes of maize: a review
}

\author{
Y Barrière*, O Argillier \\ INRA, Station d'Amélioration des Plantes Fourragères, F86600 Lusignan, France
}

(Received 21 May 1993; accepted 23 September 1993)

\begin{abstract}
Summary - The efficiency of forage for ruminant animals primarily depends on cell-wall constituent content, mostly cellulose and hemicellulose, and on their digestibility, mostly reduced by lignin incrustration. Four brown-midrib genes (bm1, bm2, bm3 and bm4) have been described in maize. Brown-midrib plants were described as having a lower lignin content than normal genotypes; the ratios of hydroxycinnamic acids released after alkaline hydrolysis, and the ratios between monomeric units released after alkaline nitrobenzene oxidation or thioacidolysis also differed in normal and brown-midrib plants. The bm3 gene, allowing an important decrease of lignin content, and a better improvement in plant digestibility, was also the most studied. When cattle were fed $b m 3$ plants, intake and digestibility were higher compared to normal isogenic ones, and the rate of digestion was also higher. However, the agronomical value of the brown-midrib genotypes was distinctively lower than that of their normal isogenic counterparts and this was particularly notable on the $b m 3$ gene. This observation also appeared to be genotype-specific, suggesting the possibility of producing brown-midrib genotypes that are practically as good as the normal ones, but only when using well-adapted breeding methods, with normal lines of a very high agronomical value.
\end{abstract}

\section{maize / brown-midrib genes / feeding value / lignin / agronomic value}

Résumé - Les gènes brown-midrib chez le maïs. Revue bibliographique. L'utilisation des fourrages par les ruminants dépend essentiellement de la teneur en constituants pariétaux, principalement cellulose et hémicelluloses, et de leur digestibilité, réduite particulièrement par la présence de lignines dans ces parois. Quatre gènes brown-midrib ( $\mathrm{bm} 1, \mathrm{bm} 2, \mathrm{bm} 3, \mathrm{bm} 4$ ) ont été mis en évidence chez le maïs. Les plantes brown midrib diffèrent des maïs normaux, particulièrement par une teneur réduite en lignines, par des rapports modifiés, entre les acides hydroxycinnamiques libérés après hydrolyse alcaline des lignines, et par des rapports également modifés entre les unités monomériques libérées après oxydation alcaline au nitrobenzène ou thioacidolyse de cette lignine. Le gène bm3, qui conduit à une forte réduction de teneur en lignines et surtout, résultat obtenu dès les premières mesures de digestibilité in vitro, à la plus importante augmentation de digestibilité, a fait l'objet du plus grand nombre d'études. Cela a permis de confirmer que les génotyes bm3 étaient mieux ingérés par les ruminants, avaient, in vivo, une meilleure digestibilité, avec une vitesse de digestion plus élevée. En revanche, la valeur agronomique des maïs brown-midrib est plus faible que celle des maïs normaux, particulièrement en ce qui concerne le gène bm3. Cependant la variabilité génétique mise en évidence pour des caractères agronomiques suggère qu'il doit être possible d'obtenir des génotypes bm3 pratiquement du niveau des génotypes normaux, à condition d'employer des méthodes de sélection adaptées, et en n'introgressant que les lignées normales de très bon niveau agronomique.

maïs / brown-midrib / valeur alimentaire / lignine / valeur agronomique

* Correspondence and reprints 


\section{INTRODUCTION}

According to Jorgenson (1931), the first brownmidrib maize plants appeared in a $1-\mathrm{yr}$ selfpollinated line of north-western dent corn, at the University Farm, St Paul, Minnesota, in 1924. The brown-midrib maize plants exhibit a reddishbrown pigmentation of the leaf midrib, that becomes visible in plants at the 4-6 leaf stage. The pigmentation appears in the stem with its lignification visually associated with rind and vascular bundles. Whilst maturing, the coloration fades and may disappear on leaves, but remains in the stalks.

The first studies of linkage relations were done by Eyster (1926), but most of the morphologic and genetic descriptions of this type were made by Jorgenson (1931). Subsequently, this gene was named $b m 1$, and 3 other genes inducing the brown-midrib phenotype were described, bm2 (Burnham and Brink, 1932), bm3 (Emerson et al, 1935) and bm4 (Burnham, 1947). These 4 genes originated from natural mutations. They are not alleles, and each segregates as a simple Mendelian recessive character. They were located on chromosomes 5, 1, 4 and 9 of maize respectively, $b m 1$ and $b m 3$ near the respective centromers, and bm2 and bm4 close to the respective extremities of the longer arms (Neuffer et al, 1968).

Approximately $40 \mathrm{yr}$ after their discovery, the brown-midrib mutations appeared to have a drastic effect on lignin quantity and quality, and later still, to improve the digestibility of plants in ruminants. Natural or artificial brown-midrib mutants of maize, sorghum, sudangrass or pearl millet also offer a unique model for studying lignification, cell-wall phenolics, carbohydrates complexes and utilization of forage by rumen microorganisms. A synthesis of the potential of brownmidrib mutants for improvement of $\mathrm{C} 4$ graminaceous forage quality has been described by Cherney et al (1991). The present paper is devoted to an extensive discussion of studies concerning brown-midrib mutants of maize, with chronological and thematic standpoints; a synthesis is attempted in the final part of this text. The first studies performed on brown midrib dealt with lignin content and composition, and feeding value estimated by in vitro digestibility in order to compare normal plants and often the various brown-midrib mutant genes $b m 1, b m 2$, $b m 3$ and $b m 4$. Later, the studies were essentially concerned with $b m 3$ maize plants and to a lesser extent with $b m 1$; cell-wall constituent contents and compositions were measured, feeding values were estimated by in vitro and in vivo digestibility, and agronomic values and mechanical properties were observed.

\section{LIGNIN BIOCHEMICAL COMPOSITION}

Some data on lignin biochemical composition, regardless of the plant species, but more specifically for gramineous plants, should be discussed before further investigating maize brown-midrib materials. Lignins are tridimensional molecules resulting from the polymerization of 3 hydroxycinnamic alcohols. These alcohols originate from 3 hydroxycinnamic acids, $p$-coumaric acid, ferulic acid and sinapic acid. The monomeric phenylpropane units are linked through ether or carboncarbon linkages to build the lignin. The most frequent linkage is the $\beta-O-4$ ether linkage (Monties, 1989; Lewis and Yamamoto, 1990; Lapierre, 1992). Alkaline nitrobenzene hydrolysis of the lignin releases 3 aldehydes, $p$-hydroxybenzaldehyde, vanillin and syringaldehyde. Hydroxycinnamic acids are also directly bound to lignin: $p$-coumaric acid is mostly esterified (ester bonds are alkali-labile) and ferulic acid esterified or etherified. Ferulic acid and some $p$-coumaric acid are bound to hemicellulose through an ester linkage to lateral arabinose chains of arabinoxylans (Kato and Nevins, 1985; Mueller-Haney and Hartley; 1986; Nishitani and Nevins, 1987; Hartley et al, 1990; Ishii et al, 1990). These 2 acids could therefore cross-link lignin and hemicellulose (Morrison, 1974; Burritt et al, 1984; Scalbert et al, 1985; Jung, 1989; liyama et al, 1990; Kondo et al, 1990). For instance, Helm and Ralph (1991) reported the possibility of an ether linkage between lignin and ferulic acid, and of an ester linkage between this ferulic acid and an arabinoxylan.

\section{COMPARISON OF LIGNIN CONTENT AND COMPOSITION BETWEEN NORMAL AND BROWN-MIDRIB MAIZE}

\section{Lignin content}

Kuc and Nelson (1964) first pointed out that the stalks and leaves of $b m 1$ plants had a lower Ross-Potter lignin content than non-mutant 
plants (18.5 and $21.8 \%$ of the cell-wall residue, respectively, average values of 4 sampling times after sowing). The 4 brown-mibrid genes were studied a few years later by Kuc et al (1968) $(b m 1, b m 2, b m 3, b m 4$ and the double recessive mutants), who noted a difference in content of between 3.0 to 3.5 percent unit of dimethylformamide (DMF) lignin in the stalk cell wall of normal plants and brown-midrib mutants, but no significant difference between the various brown-midrib genes. However, the double mutants had an even smaller lignin content. Lechtenberg et al, (1972) re-compared the $4 \mathrm{bm} 1, b m 2, b m 3$ and $b m 4$ genes with the Troyer red (Tr) inbred line, which was harvested at 35 and/or $55 \mathrm{~d}$ after silking. Hybrid pools, segregating for the brownmidrib mutants $b m 1, b m 2, b m 3$, were simultaneously studied. The smallest acid detergent lignin (ADL) content of stover dry matter was only found in the genotypes $b m 3$ and $b m 1 b m 3$ whereas the other genotypes shared similar values to those of the normal genotypes. Muller et al (1971) who also worked with the Tr inbred, established that the ADL content in plants harvested $35 \mathrm{~d}$ after flowering, was lower in the $\mathrm{bm} 3$ plants $(4.4 \%)$ than in the bm1bm3 $(4.6 \%)$, the $b m 1$ $(5.1 \%)$ and the normal plants $(6.1 \%)$. ADL of the leaf blades and sheaths in normal plants was also higher than in the 3 other genetic types; ADL in the stalks of the $b m 3$ and $b m 1 b m 3$ was lower than in the $b m 1$ and normal plants. Whilst studying the $\mathrm{Tr}$ inbred and its isogenic mutant $b m 1$, Cymbaluk et al (1973) found that the bm1 stalks were poorer in AOAC lignin content (sulphuric acid lignin in dry matter).

All the subsequent studies performed with normal and $b m 3$ maize plants showed reduced contents of lignin in $b m 3$, regardless of the methods of analysis used (Kuc et al, 1968; Muller et al, 1972; El-Tekriti et al, 1976; Frenchick et al, 1976; Keith et al, 1981; Stallings et al, 1982; Weller et al, 1984; Grand et al, 1985; Gupta et al, 1988; Inoue and Kasuga, 1989, 1990; Grenet and Barry, 1991; Chabbert et al, 1993a, 1993b; Cone and Engels, 1993). When investigated, this result proved to be true for each part, or cell-wall part, of the plant such as the leaf blade, the sheath and the stem. Sheldrick (1979) demonstrated, using the Tr inbred, that the difference in lignin content under warm and sunny conditions could also be found when cropped in field conditions in the south of England, showing a reduction of $30-$ $40 \%$ in bm3 plants.

The genetic aspects of lignin content have also been investigated. During a comparative study of normal genotypes and double mutants, mainly involving the $b m 1$ gene, Miku et al (1980) noticed a significant influence of the normal genome background on the lignin content of the stalks and leaves, and genome $x$ brown-midrib genes interactions. On $21 \mathrm{bm} 3$ late hybrids representing a 7-parent diallel and their isogenic normal counterpart hybrids, Gentinetta et al (1990) observed an average lignin content of $\mathrm{bm} 3$ hybrids equal to $63.8 \%$ that of normal hybrids. The variability in lignin content between hybrids was similar for normal and $b m 3$ hybrids, showing a predominance of specific combining ability (SCA) effects over general combining ability (GCA), with a GCA/SCA ratio equal to 0.8 .

\section{Contents in hydroxycinnamic acids bound to lignin}

Kuc and Nelson (1964) first established that, after the release of esterified aromatic compounds by mild alkaline hydrolysis, normal plants displayed, at all growth stages, a higher amount of p-coumaric acid than $b m 1$, with only a small difference in the amount of ferulic acid. Similarly, alkaline hydrolysis of DMF lignin yielded equal quantities of ferulic acid from normal and bm1 plants, but almost $50 \%$ less $p$ coumaric acid from bm1 plants (Gee et al, 1968). Studying the DMF lignin of the stalks of the normal and $b m 1 \mathrm{Tr}$ inbred lines, Cymbaluk et al (1973) pointed out a higher content of $p$ coumaric and ferulic acids in the dry matter of normal $\operatorname{Tr}$ material than in the $b m 1$ tissues, with a most significant decrease of the $p$-coumaric acids in $b m 1$ plants. When comparing the 4 brown-midrib genes, Kuc et al (1968) noted that normal plants and brown-midrib mutants contained the same percentage of ferulic acid, whereas a higher content was found in double mutants. The yield of $p$-coumaric acid appeared to be reduced only for the $b m 1$ gene, and especially in the double mutants containing the gene $b m 1$. Contrary to this study, the reduced yield of p-coumaric acid was later proved to be true for the $b m 3$ and $b m 2$ genes. Hartley and Jones (1978), studying the normal and $b m 3 \mathrm{Tr}$ inbred lines, observed in each of the vegetative organs (leaf blade, leaf sheath and stem) a ratio of $p$-coumaric/ferulic acid inferior in bm3 plants compared to normal plants. Similarly, Cherney et al (1989), reported a lower $p$-coumaric acid content in bm3 tissues compared to normal tis- 
sues of the fifth internode of the stem, whereas the ferulic acid content was similar for bm3 and normal internodes. Finally, Chabbert et al (1993a) confirmed a lower ratio of $p$-coumaric/ ferulic acid, after alkaline hydrolysis, in internodes of bm3 plants as compared to normal plants; and from a comparison of non-isogenic materials, bm2 plants appeared with an intermediate ratio of $p$-coumaric/ferulic acid between normal and $b m 3$ plants, closer to normal than to bm3 plants (Chabbert et al, 1993b).

\section{Lignin composition}

In measuring the products of an alkaline nitrobenzene oxidation of lignin, Kuc and Nelson (1964) first pointed out that the yield of phenolic monomers was considerably reduced in bm1 plants, about 4 times lower, indicating a larger amount of residue resistant to nitrobenzene oxidation, but the ratios of syringaldehyde, vanillin and $p$-hydroxybenzaldehyde to total aldehydes, and the ratio of syringaldehyde to vanillin, were the same for normal and bm1 plants. Gee et al (1968) confirmed these results with DMF lignin, $b m 1$ plants yielding lower amounts of the 3 aldehydes after alkaline nitrobenzene oxidation. They also pointed out that the DMF lignin of the bm1 plant contained more carboxyl groups than the DMF lignin of normal plants; $b m 1$ DMF lignin had more alkali-labile bonds. Studying the $\mathrm{Tr}$ inbred and its isogenic mutant bm1 Cymbaluk et al (1973) also reported that the DMF-lignin of the bm1 stalk tissues displayed less of the 3 aldehydes than normal plants, and particularly almost 2.5 times less syringaldehyde. When they compared the 4 brown-midrib genes, Kuc et al (1968) reported, after a nitrobenzene oxidation of the DMF lignin, a lower ratio of syringaldehyde to vanillin for the stalks of the $b m 1$ plants, but no difference between normal and bm3 plants, and only slightly lower ratios for $b m 2$ and $b m 4$. They also pointed out a higher release of $p$ hydroxybenzaldehyde from $\mathrm{bm} 3$ and $\mathrm{bm} 4$ stalks of the plants, as compared to normal or $b m 1$ and bm2 plants.

As previously observed with $b m 1$ mutants, Grand et al (1985) found that, when the lignin was subjected to alkaline nitrobenzene oxidation, it also yielded a reduced amount of phenolic uncondensed monomers in bm3 mutants in comparison with normal plants (20-d-old corn plants of normal and bm3 inbred lines). They also dem- onstrated a reduction in the proportion of methoxylated units in the lignin, with a higher percentage in the release of $p$-hydroxybenzal-dehyde, which was lower for vanillin, and almost the same for syringaldehyde. They particularly emphasized the low catechol O-methyl transferase (OMT) activity of the bm3 plants. This was confirmed by Cherney et al (1989) who reported a lower specific activity of OMT in meristems and tissues of $b m 3$ internodes, compared to normal internodes, harvested $58 \mathrm{~d}$ after planting. Lapierre et al (1988) performed the lignin characterization by analysis of the degradation products recovered from thioacidolysis, on internodes of normal and bm3 maize plants, harvested at grain maturity. In this way, they revealed a drastic decrease of the syringyl/guaiacyl ratio in recovered products, in the case of $b m 3$ compared to the normal line (0.39 in bm3 compared with 1.72 in normal plants), which emphasizes that it is essentially the biosynthesis of syringyl units which is affected by the bm3 mutation. Similar results were reported by Gaudillière and Monties (1989). Lapierre et al (1988) also found evidence of an unusual compound, the 5-hydroxyguaiacyl unit, which is a characteristic of $b m 3$ plants and only found as traces in normal plants. This could suggest that the main step affected by the bm3 mutation is the methylation of 5-hydroxyferulic acid, catalyzed by a catechol $O$-methyl transferase. $\mathrm{Fi}$ nally research undertaken by Chabbert et al (1993a) with 3 different normal and $b m 3$ maize hybrids showed a lower syringyl/guaiacyl ratio after thioacidolysis in bm3 plants compared with normal plants, which was in agreement with the study of Lapierre et al (1988). A complementary result was recently obtained by Chabbert et al (1993b), with a higher syringyl/guaiacyl ratio in bm2 plants, as compared to normal and bm3 plants.

From previous studies, brown-midrib plants yielded lower amounts of monomeric units after alkaline nitrobenzene oxidation. The lignin of brown-midrib plants thus appeared as a more condensed polymer than the lignin of normal plants. Nuclear magnetic resonance spectra obtained on alkali-lignins and DMF-lignins extracted from corn stalks of the $T r$ inbred line, normal and bm1 (Gordon and Griffith, 1973) revealed that the $b m 1$ lignin has a higher degree of crosslinking in the propane side chain of the lignin molecule than in normal lignin. Thus, the normal Tr line lignin seems to be a less-condensed polymer than the $b m 1$ one. 


\section{VARIABILITY OF CELL-WALL CONTENT AND CELL-WALL CARBOHYDRATE CONTENT OF THE NORMAL AND BROWN-MIDRIB MAIZE}

\section{Cell-wall content}

Lechtenberg et al (1974) demonstrated, on segregating populations, that the cell-wall contents were nearly the same for $b m 3$ and for normal corn stover silages and stalks. However, ElTekriti et al (1976) found that the cell-wall content appeared lower in the bm3 stalks and leaves of segregating populations. This result was confirmed by Frenchick et al (1976) with a cell-wall content of $53.7 \%$ for the bm3 silage (whole plants) and $59.5 \%$ for the normal. A2-yr study was conducted by Keith et al (1981), which showed that the cell-wall content did not differ between $b m 3$ and normal silage (whole plants) in $\mathrm{yr}$ 1 but that it was lower for the bm3 in yr 2. Cone and Engels (1993) showed a significantly lower NDF content of a $b m 3$ hybrid, compared with its normal counterpart. The generally lower cell-wall content for the bm3 plant resulted, at least in part, from a reduced lignin content.

\section{Cellulose content}

The cellulose content, as a percentage of dry matter, was estimated according to a Van Soest procedure in all the work reported here (Van Soest, 1963, 1965, 1967; Goering and Van Soest, 1970). According to Muller et al (1971), the cellulose content of the double mutant $\mathrm{bm} 1 \mathrm{bm} 3$ was inferior to that of $b m 1, b m 3$ and normal plants. Using plants ensiled without ears, Muller et al (1972) found similar cellulose contents in normal and $b m 3$ mutants $(28.9 \%$ and $29.0 \%)$. Lechtenberg et al (1972, 4 brown-midrib genes; 1974, bm3) demonstrated, with $\mathrm{Tr}$ inbred lines and on segregating populations, that the cellulose contents were nearly the same for brownmidrib and for normal maize stovers and stalks. In a 2-yr study, Keith et al (1981) found cellulose contents consistent with the first 2 results. Finally Weller et al (1984), working with normal and $b m 3$ maize plants of 3 genotypes (INRA 188, INRA 240 and INRA 258), which were harvested at 3 stages of maturity, and Cone and Engels (1993) with LG 11, which was harvested 9 times between mid-July and mid-November, found similar cellulose concentrations in both normal and $b m 3$ plants.
When the cellulose content was estimated through the crude fiber content, no significant difference was observed between normal and bm3 genotypes (Frenchick et al, 1976; Inoue and Kasuga, 1989, 1990; Barrière et al, 1993).

\section{Hemicellulose content}

The hemicellulose content was estimated according to similar Van Soest procedures as for the cellulose content. The hemicellulose content was the same for normal, bm 1 and $b m 3$ plants, but with a trend for higher values in the $b m 1 b m 3$ plants (Muller et al, 1971). Using plants ensiled without ears, Muller et al (1972) found an hemicellulose content slightly higher for $b m 3$ than for normal plants (22.8 and $21.7 \%$ ). When comparing the 4 brown-midrib genes, Lechtenberg et al (1972) reported that the stalks and stovers of brown-midrib mutants displayed a slightly higher percentage of hemicellulose. In the study of ElTekriti et al (1976), the hemicellulose content was also higher in the $b m 3$ stalks and leaves than in normal ones. Cone and Engels (1993) later observed increasing differences in hemicellulose content, with a higher value for the $b m 3$ hybrid, when estimated as a percentage of the cell-wall content during the cropping season, and especially when related to the decreasing difference in cell-wall content between hybrids during ageing. However, for the first year of their study, Keith et al (1981) found no differences between $b m 3$ and normal silage for the hemicellulose content, whereas in the second year, the hemicellulose content was significantly higher for normal than for bm3 silage; Weller et al (1984) reported similar hemicellulose concentrations in both normal and bm 3 plants.

\section{COMPARISONS OF THE FEEDING VALUE BETWEEN NORMAL AND BROWN-MIDRIB MAIZE}

\section{In vitro studies}

Barnes et al (1971) reported the first studies on a normal inbred and 3 brown-midrib genotypes (bm1, bm3 and the double recessive mutant $b m 1 b m 3)$, which were developed in the $\operatorname{Tr}$ inbred line background, and harvested at 10, 35 and $55 \mathrm{~d}$ after silking, using a Tilley and Terry (1963) method. Research on the different plant 
parts has proved that the in vitro digestibility of the $b m 3$ vegetative organs (stem, leaf, sheath, cob, husk) was superior, whereas the in vitro digestibility of the grain was comparable. The $b m 1$ genotype was often closer to the normal type than to the $b m 3$, and the bm1bm3 type was intermediate, or similar to the $b m 3$.

Lechtenberg et al (1972) were the first to compare the in vitro feeding values of the $4 \mathrm{bm} 1$, $b m 2, b m 3$ and $b m 4$ genes with the $\mathrm{Tr}$ inbred, which was harvested at 35 and $55 \mathrm{~d}$ after silking. Hybrid pools, segregating for the brown-midrib mutants $b m 1, b m 2$, and $b m 3$, were simultaneously studied. Digestibility was particularly improved with the $b m 3$ and the $b m 1 b m 3 T r$ inbred, with a similar observation made for bm3 hybrids. These results were in close correlation with the $A D L$ content of the different genotypes. Whilst studying the $\mathrm{Tr}$ inbred and its isogenic mutant bm1, Cymbaluk et al (1973) found a higher in situ digestibility of the $b m 1$ stalks.

Lechtenberg et al (1974) demonstrated that the amounts of cell wall and cellulose digested during a 72-h in vitro study on segregating populations were considerably greater for $b m 3$ stalks than for normal ones. Similarly, El-Tekriti et al (1976) demonstrated that the in vitro dry matter disappearance, determined using the technique of Tilley and Terry (1963), was clearly higher in the organs (stems and leaves) of the $b m 3$ plants. Working with the Tr inbred, Hartley and Jones (1978), also demonstrated a greater enzymatic degradation of $b m 3$. These results were confirmed by Weller et al (1984), who found that the in vitro digestible organic matter in the dry matter values were significantly higher for the $b m 3$ ( $p<$ 0.05 ) than for their normal counterparts, and by Gupta et al (1988) who reported that $b m 3$ lines had higher in vitro dry matter digestibility. Comparing bm3 plants to normal ones, within the progeny of a 3-way hybrid including a normal line in the female single cross, Inoue and Kasuga (1989) pointed out a higher enzymatic digestibility of the organic matter of the stover, a little lower than 4 percent units. When comparing normal plants and bm3 plants, Grenet and Barry (1991) demonstrated a faster rate of in sacco degradation of $b m 3$ genotypes. They outlined very different degradation processes with observations made by scanning electron microscopy. The histological structure of the 2 maizes was the same, but after $24 \mathrm{~h}$ in the rumen the parenchyma of the bm3 maize degraded faster and the secondary walls of the fibers of its vascular bundles were degraded whereas those of normal maize remained intact. After $72 \mathrm{~h}$ in the rumen, the sclerenchyma of normal maize changed little, whereas the $b m 3$ maize had much thinner walls and was abundantly colonized by rumen bacteria. New results by Cone and Engels (1993), comparing a $b m 3$ hybrid and its normal counterpart harvested 9 times from mid-July to midNovember, showed that the difference in lignin content (ADL, as a percentage of dry matter) decreased during the latter part of the cropping season, after the harvest silage period, and similarly the in vitro rumen fluid digestibility (Engels and Brice, 1985) of the cell wall of the 2 types of hybrids were closer during that period. In connection with the apparently more condensed characteristic of the brown-midrib lignin polymer, Thorstensson et al (1992) considered that, with equal amounts of lignin, the $b m 3$ plant lignin could show an apparently greater inhibition to the digestion of polysaccharides than normal plant lignin. Studies performed by Köhler et al (1989, 1990) with normal maize hybrids and brownmidrib hybrids (the types of brown-midrib genes were not clearly indicated), seemed to show an increased digestibility of neutral detergent fiber (NDF), acid detergent fiber (ADF) and hemicellulose in some brown-midrib hybrids and, at the same time, a lower lignin content.

\section{Experiments with sheep}

Studying the $\mathrm{Tr}$ inbred and its isogenic $b m 1$ counterpart, Gordon and Neudoerffer (1973) found that $b m 1$ appeared to have a slightly higher digestibility of dry matter and fiber in sheep. The in vivo experiments undertaken on lambs by Muller et al (1972), using plants deprived of ears, showed increased intake by lambs of $b m 3$ corn silage and demonstrated that animals that were fed with bm3 ad libitum or rationed at $90 \%$ of ad libitum intake, showed an increase in cellulose digestibility of 8.7 and 6.9 percent units respectively, and similarly of 12.5 and 6.2 in hemicellulose digestibility (cellulose and hemicellulose according to Van Soest, as a percentage of dry matter). During a digestibility experiment (Stallings et al, 1982), sheep consumed significantly more $b m 3$ than normal silage dry matter (1.36 and $1.15 \mathrm{~kg} / \mathrm{d}$ ) and apparent dry matter digestibility was greater for $b m 3$ silage than normal $(70.4$ and $64.3 \%$ ); the same was true for the apparent ADF digestibility ( 61.8 and $46.8 \%$ ). During 2 tests, Weller and Phipps (1986) compared normal and $b m 3$ maize silages, which were fed to 
sheep. In both experiments, the $b m 3$ gene significantly increased the digestibility of the organic matter, cell-wall constituents, ADF and cellulose, whereas, in the first test, the digestibility of hemicellulose was greater with the $b m 3$, but in the second test, the digestibility of the hemicellulose was similar in both silages. Barrière et al (1985), with results amounting to 10 years of experiments on sheep confirmed a greater intake of bm3 (average 5.3\%), an increase in organic matter digestibility (average $3.5 \%$ ) and a great improvement in cellulose digestibility by an average of $15.6 \%$. Recent studies undertaken by INRA at Lusignan have strengthened and refined these points (Barrière et al, 1993).

\section{Experiments with goats}

Whether fresh plants or silage were offered, the dry matter intake of goats was higher with $b m 3$ hybrids (114\%) as compared to normal ones $(100 \%)$; but the milk yield was similar with the 2 types of hybrids (Gallais et al, 1980). With wholeplant silage of normal maize plants and their bm3 isogenic counterparts, Inoue and Kasuga (1990) reported that the digestibility of organic cell wall and crude fiber, when tested in digestion experiments on goats, was 16 and 11 percent units higher, respectively, for $b m 3$ hybrids; the digestibility of the residue of organic cell wall without crude fiber was also 15 percent units higher for bm3 plants, indicating a significant improvement of the digestibility of both cellulose and hemicellulose in the cell walls of $b m 3$ maize.

\section{Experiments with cattle}

The first tests were conducted on heifers in 1972 , 1973 and 1975 by Colenbrander et al. They noted superior intake and body weight gain in animals fed $b m 3$ silage, as opposed to normal genotypes. Keith et al (1981) conducted a study to compare the performances of feedlot cattle fed either $b m 3$ maize silage or its normal genetic counterpart with or without different levels of additional grain maize. They found that the feeding of $b m 3$ silage resulted in a significantly greater cattle body weight gain when no additional grain maize was fed, but no difference in body weight gain was observed when grain was fed at $2 \%$ of the body weight. Malterre et al (1985) demonstrated that $b m 3$ maize was better ingested in young bulls, allowing greater body weight gain when fed with similar supplements. When the supplements were reduced, the young bulls fed silage of bm3 plants, greatly increased their intake and maintained a slightly superior body weight gain. Tests performed by INRA at Lusignan showed that zootechnic performances of young bulls fed with $b m 1$ maize silage were lower than those of young bulls fed with $b m 1$ maize, even if the $b m 1$ genotype was slightly more efficient than the normal genotype (Barrière et al, 1993).

A greater intake of $b m 3$ maize was observed in dairy cows in North America by Rook et al (1977), Sommerfeldt et al (1979), Block et al (1981), Stallings et al (1982), but similar observations were not conclusive in studies made by Frenchick et al (1976) or Keith et al (1979). Rook et al (1977) and Stallings et al (1982) found similar milk production between $b m 3$ and normal groups, while Frenchick et al (1976), Sommerfeldt et al (1979), and Block et al (1981) found slight trends to higher milk production in cattle fed $b m 3$ hybrids. A significant increase in milk was only observed once under US feeding conditions (Keith et al, 1979). Actual and fatcorrected milk yields were 1.3 and 0.9 kg greater for cows fed bm3 silage than for cows fed normal silage at a forage-to-concentrate ratio of 72:25. Yields were 1.6 and $1.0 \mathrm{~kg}$ greater for actual and fat-corrected milk, for cows fed $b m 3$ hybrids compared with those fed normal silage at $60: 40$. Increased body weights of cows fed bm3 corn silage were noted every time this trait was observed (Frenchick et al, 1976; Rook et al, 1977; Keith et al, 1979; Sommerfeldt et al, 1979; Stallings et al, 1982). It thus appeared that energy intake was apparently not limiting for milk production and it seemed that the extra nutrients available from the greater intake and digestibility were partitioned more into meat or fat body tissues than in milk production.

In the United Kingdom, the effect of feeding bm3 silage to cattle was studied by Weller and Phipps (1986). In a 28-d trial, 6 Friesian cows, in weeks $27-30$ of lactation, were offered a diet in which $30 \%$ of the dry matter consisted of concentrates and $70 \%$ was either normal or $b m 3$ silage. They confirmed a greater intake of the bm3 maize and found that in vivo digestibility of the dry matter, organic matter, cell-wall constituents, ADF, cellulose and hemicellulose were higher in the bm3 diet. They also reported that cows fed the $b m 3$ diet produced more milk (15.9 compared with $13.4 \mathrm{~kg} / \mathrm{d}$ ), with no difference in 
milk composition, and had a higher average daily live-weight gain.

Under French rearing conditions, with cows fed a $b m 3$ or normal silage with the same energizing supplements, Hoden et al (1985) confirmed better intake of $b m 3$ maize, but with only a small improvement in zootechnic performance. A reduction of $1.3 \mathrm{~kg}$ in the dried energizing supplements fed to animals receiving $b m 3$ silage allowed a large increase in the quantities being ingested and a higher production in milk.

\section{MECHANICAL PROPERTIES AND AGRONOMICAL VALUES}

While comparing bm 3 mutants and normal counterparts of 3 maize single crosses, Zuber et al (1977) pointed out that bm3 plants had between 17 to $26 \%$ less crushing strength of the dry third internode; the weight of a given segment was lower but the thickness of the rind was similar. This was also confirmed by Weller et al (1985). Four normal hybrids and $b m 3$ showed higher resistance to crushing and greater stem weight in the normal genotypes but a similar rind thickness. Although the $b m 3$ gene slightly increased root lodging, susceptibility to lodging was mostly explained by the genetic background of the hybrids. Similarly the previously described study, by Gentinetta et al (1990), of 21 bm3 hybrids representing the 7-parent diallel and their isogenic normal counterpart hybrids, highlighted that $b m 3$ hybrids had slightly more stalk breakage than normal plants, but the differences between normal hybrids were not significant, while a significant genetic variability existed between $b m 3$ hybrids. Some $b m 3$ hybrids had no more stalk lodging than their corresponding normal counterparts. Genotypes bm3 appeared to be more susceptible to breakage, when equally infected with stalk-rot or infested with European corn-borer (Anglade, Gallais and Barrière, unpublished data). However, when breeding for a stronger resistance of $b m 3$ genotypes to lodging, Nesticky and Huska (1985) obtained lines that did not differ in puncture strength for stalk penetration as opposed to normal control.

Apart from the mechanical properties of the stems, the agronomical value of the brownmidrib genotypes seemed distinctively inferior to that of their normal isogenic counterparts and this was particularly noticeable for the $b m 3$ gene. This gene delayed silking by approximately $5 \mathrm{~d}$, decreased the dry matter content at silage harvest and decreased the grain and biomass yields by up to $20 \%$ (Gallais et al, 1979, 1982; Weller et al, 1985). Inoue and Kasuga (1989) also pointed out a significant decrease of the grain and biomass yields of $b m 3$ plants, but they observed no difference for early vigor and no variation of earliness, neither at tasseling or silking time, nor for days to yellow ripe stage. Miller and Geadelmann (1983) have observed lower seedling dry weights and lower dry matter accumulation rates during vegetative growth in $\mathrm{S} 1 \mathrm{bm} 3$ lines compared with the normal S1 lines, using pools with narrow base germplasm. Furthermore, after topcrossing, S1 bm3 progenies produced lower grain and whole plant yields, 77 and $90 \%$ respectively, when compared with normal S1 progenies (Miller et al, 1983). Recurrent selection attempted on original $b m 3$ silage genotypes was unable to yield material with reasonable agronomical value (Barrière et al, 1988b), but there might be a possibility for improvement from pedigree breeding from entries of a very high agronomic value (Barrière et al, 1988a, 1993).

Studies on $15 \mathrm{bm} 3$ late hybrids, representing a 6-parent diallel and on their 15 isogenic normal counterpart hybrids, were undertaken in Hawaii (Lee and Brewbaker, 1984). They observed a grain yield and a stover yield in $b m 3$ hybrids of 80 and $83 \%$, respectively, of the normal hybrids, without modification of the silking dates. The leaf area index (LAI) of bm3 hybrids was not significantly inferior to that of normal plants, whereas the stem diameter of $b m 3$ plants was significantly inferior. For grain yield, the GCA effects were similar between normal and bm3 plants, but for stover yield the GCA effects were lower in the bm3 hybrids. It was also observed that the SCA effects were inferior for $b m 3$ hybrids. A significant predominance in GCA effects appeared in all cases. All hybrids that have been tested showed a decrease in whole plant yield of at least $10 \%$ over the normal types. Similarly Gentinetta et al (1990) observed on the previously described diallel that the whole plant yield of the $b m 3$ hybrids was equal to $84 \%$ of the normal ones, but with a slightly superior earliness in $b m 3$ hybrids. Contrary to what had been previously observed and following the observations made by Lee and Brewbaker (1984), the decrease in yield affected on average the grain part as much as the stover parts. The variability in productivity was significantly superior among normal hybrids, with mean squares nearly double for whole plant yield, and a particularly low mean square for the 
stover yield of $b m 3$ hybrids. This mean square was lower than expected from a proportional decrease of yield of each hybrid. In the same way the GCA/SCA ratios were superior in normal hybrids, due to the higher GCA values and the proportionally lower SCA values. Out of $21 \mathrm{bm} 3$ hybrids, 3 displayed a whole plant yield equal to $95 \%$ of the normal corresponding plants; one of them even appeared slightly superior. Moreover, these 3 hybrids corresponded to the sub-diallel of 3 inbred lines $(B 77 \mathrm{bm} 3, C 103 \mathrm{Dbm} 3$ and $\mathrm{H} 28 \mathrm{bm} 3)$.

\section{DISCUSSION AND CONCLUSIONS}

The effects and characteristics of the 4 brownmidrib genes were not equally investigated. Preliminary work dealt either with the $b m 1$ gene, or with all 4 genes. From 1973 to 1974, most work only dealt with the $b m 3$ gene, and this is probably due to the results of Barnes et al (1971) and Lechtenberg et al (1972) proving a higher digestibility of bm3 plants, as compared to normal ones or to other brown-midrib ones.

Some typical characteristic of brown-midrib genotypes can be pointed out, as illustrated in table I from papers giving comparisons of the different brown-midrib genes. It is worth noticing that the results of Kuc et al (1968) may appear contradictory to those obtained later, especially for some characteristics of lignin of $b m 3$ maize.
The brown-midrib mutants are mainly recognized by their reduced lignin content, even though the ranking of the genes for this feature and the importance of the decrease may depend on the way the lignin is measured and of the genetic backgrounds of the plants. This reduction in lignin content appears even more impressive in some double mutants, although this still needs to be confirmed. Differences in the lignin composition and in the ratios of the esterified phenolic acids are also conclusively demonstrated. The amount of esterified ferulic acid appears to be nearly similar in both normal and brown-midrib plants, while the $p$-coumaric acid amount is lower in bm1 and bm 3 plants. According to the different papers, the release of aldehydes after use of nitrobenzene oxidations is much lower in bm1 and/or bm3 lignins, as compared to normal lignins. Brown-midrib lignin appears as a more condensed polymer than the normal one. At the same time, the ratios of syringaldehyde to vanillin are different in normal and brown-midrib plants. After thioacidolysis, the lignin also yields lower syringyl/guaiacyl ratios in bm3 plants compared with normal ones. Moreover, $b m 3$ plants are also characterized by an original 5-hydroxy-guaiacyl unit, which appears after thioacidolysis as well as through a lack of catechol $O$-methyl transferase activity.

Finally, after in vitro experiments pointing out the higher digestibility of $b m 3$ plants, the interest of the brown-midrib genotypes was established because they provide greater intake and digesti-

Table I. Some characteristic results illustrating the effects of the 4 brown-midrib genes of maize.

\begin{tabular}{llrrrrr}
\hline Reference & Character studied & normal & bm1 & bm2 & bm3 & bm4 \\
& & & & & & \\
\hline & & & & & & \\
Kuc et al, 1968 & DMF lignin, stalks a & 24.5 & 21.0 & 22.0 & 21.0 & 21.4 \\
Lechtenberg et al, 1972 & ADL, stover, \% dry matter b & 7.8 & 7.1 & 6.8 & 5.3 & 7.3 \\
Chabbert et al, 1993b & Klason lignin, stalks c,d & 16.0 & $(12.6)^{\mathrm{k}}$ & 10.9 & 12.0 & - \\
Kuc et al, 1968 & p-coumaric/ferulic e & 3.6 & 1.7 & 2.9 & 3.1 & 3.3 \\
Chabbert et al, 1993b & p-coumaric/ferulic cf & 4.6 & $(4.8)^{\mathrm{k}}$ & 3.6 & 2.2 & - \\
Kuc et al, 1968 & syringaldehyde/vanillin g & 2.4 & 1.6 & 2.0 & 2.4 & 1.9 \\
Chabbert et al, 1993b & syringaldehyde/vanillin gh & 1.0 & - & 1.4 & 0.3 & - \\
Chabbert et al, 1993b & syringyl/guaiacyl c,i & 1.1 & $(1.1)^{\mathrm{k}}$ & 3.1 & 0.3 & - \\
Lechtenberg et al, 1972 & IVDMD i & 46.4 & 47.0 & 51.8 & 54.8 & 51.3 \\
\hline
\end{tabular}

a DMF lignin as a percentage of the cell wall; ${ }^{b}$ ADL of stover from Tr inbred lines harvested $55 \mathrm{~d}$ after silking; ${ }^{\mathrm{c}}$ average data of top, middle and bottom internodes of the stalks: d Klason lignin content expressed as percentage of cell-wall residue; e phenolic acids released by alkaline hydrolysis estimated as $\mathrm{mg} / \mathrm{g}$ in lignin; ${ }^{f}$ phenolic acids released by alkaline hydrolysis expressed as $\mu \mathrm{mol} / \mathrm{g}$ of the cell-wall residue; 9 products of alkaline nitrobenzene oxidation estimated as $\mathrm{mg} / \mathrm{g}$ in lignin; ${ }^{h}$ products of alkaline nitrobenzene oxidation expressed in $\mu \mathrm{mol} / \mathrm{g}$ of Klason lignin; i products of thioacidolysis expressed as $\mu \mathrm{mol} / \mathrm{g}$ of Klason lignin ; iVDMD (in vitro disappearance of dry matter) according to Tilley and Terry (1963); ${ }^{k}$ data for $b m 1$ materials (Chabbert and Tollier, personal communication) were obtained from separate comparisons of normal, bm1 and bm3 plants. All the values of normal and $b m 3$ plants were similar in the 2 experiments. 
bility, and a higher rate of digestion when they are fed to cattle. It is worth noticing that the improvement of digestibility or efficiency observed with cattle fed $b m 3$ silage was higher than expected from in vitro measurements of digestibility. In this way, Inoue and Kasuga (1989-1990) showed a higher in vitro enzymatic digestibility of the stover of bm3 plants reaching only 4 percent units compared with normal ones, while the increase of organic cell-wall digestibility estimated from experiments on goats reached 15 percent units. Similarly, from experiments with dairy cows performed in Lusignan (Hoden et al 1985), the higher energy content of $b m 3$ hybrids did not clearly appear from in vitro tests, but only from feeding cattle with diets involving a reduced content of energizing concentrates.

However, the bm3 gene delays maturity, increases lodging and/or breakage susceptibility, because of poorer mechanical properties of the stem. It also decreases grain and stover yield. But these observations also appear to be genotype-specific. This genetic variability suggests the possibility of producing brown-midbrid genotypes as good as the normal ones, provided welladapted breeding methods are used, with lines of a very high agronomical value, such as those used in the best and newly registered hybrids.

From a theoretical point of view, working with brown-midrib plants, and comparing the effects of each of the genes, is probably a major step towards understanding the lignification in gramineous plants, and the relationship between lignification and digestibility. Molecular biology, cloning of O-methyl transferase and cinnamylic alcohol dehydrogenase enzymes, use of the anti-sens RNA techniques, and cloning and sequencing brown-midrib loci of normal and mutant genotypes could be also powerful tools towards understanding lignification. Some criteria, that could be useful for plant breeders of normal silage maize, may result from theoretical work with brown-midrib maize, perhaps even before brown-mibrid hybrids with good agronomic characteristics are available.

\section{ACKNOWLEDGMENTS}

This paper is a contribution to the INRA network Agrobio-lignine. We acknowledge B Monties, B Chabbert, MT Tollier and C Lapierre for their help in our training in the biochemical characteristics of maize cell walls. We thank $M$ Rives for his helpful criticism. We also acknowledge $A$ de Pourtalès for the linguistic revision of this manuscript.

\section{REFERENCES}

Barnes RF, Muller LD, Bauman LF, Colenbrander VF (1971) In vitro dry matter disappearance of brownmidrib mutants. J Anim Sci 33, 881-884

Barrière $Y$, Gallais A, Huguet L, Traineau RT (1985) Le maïs brown midrib plante entière. I. Caractéristiques générales. Bull Tech CRZV Theix INRA 60, 43-44

Barrière Y, Gallais A, Berthet H (1988a) Utilisation du gène brown midrib-3 pour l'amélioration du maïs fourrage. I. Rétrocroisement et sélection généalogique. agronomie 8, 513-519

Barrière Y, Gallais A, Berthet H (1988b) Utilisation du gène brown midrib-3 pour l'amélioration du maïs fourrage. II. Sélection récurrente de populations. agronomie 8, 625-631

Barrière $\mathrm{Y}$, Argillier $\mathrm{O}$, Chabbert $\mathrm{B}$, Tollier $\mathrm{MT}$, Monties $B$ (1993) Breeding silage maize with brown-midrib genes. Feeding value and biochemical characteristics. agronomie 14, 15-25

Block E, Muller LD, Griel LC, Garwood JR, Garwood DL (1981) Brown-midrib-3 corn silage and heatextruded soybeans for early lactating dairy cows. J Dairy Sci 64, 1813-1825

Burnham CR (1947) Maize Genet Coop News/21, 36

Burnham CR, Brink RA (1932) Linkage relations of a second brown midrib gene $(b m 2)$ in maize. J $A m$ Soc Agron 24, 960-963

Burritt EA, Bittner AS, Street JC, Anderson J (1984) Correlation of phenolic acids and xylose content of cell walls with in vitro dry matter digestibility of three maturing grasses. J Dairy Sci 67 (6), 1209-1213

Chabbert B,Tollier MT, Monties (1993a) Biological variability in lignification of maize. Part 1: Brown midrib bm3 expression in three maize cultivars. J Sci Food Agric (submitted)

Chabbert B,Tollier MT, Monties (1993b) Biological variability in lignification of maize. Part 2: Expression of the brown midrib bm2 mutation. $J$ Sci Food Agric (submitted)

Cherney JH, Volenec JJ, Bron GA (1989) Synthesis of cell wall components in maize internodes. $\mathrm{In}$ : Proc of the XVI Inter Grassl Cong, 4-11 October 1989, Nice, France, 759-760

Cherney JH, Cherney DJR, Akin DE, Axtell JD (1991) Potential of brown-midrib, low-lignin mutants for improving forage quality. Adv Agron 46, 157-198

Colenbrander VL, Lechtenberg LF, Bauman LF, Muller LD, Rhykerd CL (1972) Nutritive value of brown midrib corn silage. J Anim Sci 35, 1113

Colenbrander VL, Lechtenberg LF, Bauman LF (1973) Digestibility and feeding value of brown midrib corn stover silage. J Anim Sci 37, 294-295

Colenbrander VL, Lechtenberg LF, Bauman LF (1975) Feeding value of low lignin corn silage. J Anim Sci 41, 332-333 abstr

Cone JW, Engels FM (1993) The influence of ageing on cell wall composition and degradability of three maize genotypes. Anim Feed Sci technol 40, 331-342 
Cymbaluk NF, Gordon AJ, Neudoerffer TS (1973) The effect of the chemical composition of maize plant lignin on the digestibility of maize stalk in the rumen of cattle. Br J Nutr 29, 1-12

El-Tekriti RA, Lechtenberg VL, Bauman LF, Colenbrander VF (1976) Structural composition and in vitro dry matter disappearance of brown midrib corn residue. Crop Sci 16, 387-389

Emerson RA et al (1935) Cornell Univ Agric Exp Stn Memoir 180

Engels FM, Brice RE (1985) A barrier covering lignified cell walls of barley straw that restricts access by rumen microorganisms. Curr Microbiol 12, 217-224

Eyster WH (1926) Chromosome VIII in maize. Science 64 (22), 22

Frenchick GE, Jonhson DG, Murphy JM, Otterby DE (1976) Brown midrib corn silage in dairy cattle ration. J Dairy Sci 59 (12) 2126-2129

Gallais A, Huguet L, Berthet $H$, Bertin G, Broqua B, Mourguet A, Traineau $R$ (1979) Feeding and agronomic value of brown-midrib maize hybrids in French conditions. In: Euromaize 79 Congress, Cambridge (ES Bunting, ed). Production and utilization of the maize crop, 379-384

Gallais A, Huguet L, Berthet H, Bertin G, Broqua B, Mourguet A, Traineau R (1980) Preliminary evaluation of brown midrib maize hybrids for their feeding and agronomic value in France. In: Improvement of quality traits of maize for grain and silage use (WG Pollmer, RH Phipps, eds), 319-339

Gaudillère M, Monties B (1989) Biochemical and biosynthetic studies in lignification of Gramineae. Plant cell-wall polymers. In: Biogenesis and biodegradation (NG Lewis, MG Paice, eds) 182-192

Gee MS, Nelson DE, Kuc J (1968) Abnormal lignins produced by the brown midrib mutants of maize. Arch Biochem Biophys 123, 403-408

Gentinetta E, Bertolini M, Rossi I, Lorenzoni C, Motto M (1990) Effect of brown midrib-3 mutant on forage quality and yield in maize. J Genet Breed 44, 21-26

Goering HK, Van Soest PJ(1970) Forage fiber analysis. USDA ARS Agr Handbook No 379

Gordon AJ, Neudoerffer TS (1973) Chemical and in vivo evaluation of a brown midrib mutant of Zea mays. I. Fibre, lignin and amino-acid composition and digestibility for sheep. J Sci Food Agric 24, 565-577

Gordon AJ, Griffith PR (1973) Chemical and in vivo evaluation of a brown midrib mutant of Zea mays. II. Nuclear magnetic resonance spectra of digested and undigested alkali lignins and undigested dimethylformamide lignins. J Sci Food Agric 24, 579-287

Grand C, Parmentier P, Boudet A, Boudet AM (1985) Comparison of lignins and of enzymes involved in lignification in normal and brown-midrib (bm3) mutant corn seedlings. Physiol Veg 23 (6), 905-911

Grenet E, Barry P (1991) Microbial degradation of normal maize and $b m 3$ maize in the rumen observed by scanning election microscopy. I Sci Food Agric $54,199-210$
Gupta HO, Singh J, Jain OP (1988) Brown midrib colour as an index of forage quality in maize (Zea mays L). In: Proc Ind Nat Sci Acad, B Biol Sci 54: 2-3, 175-178

Hartley RD, Jones EC (1978) Phenolic component and degradability of cell walls of the brown-midrib mutant bm3 of maize. J Sci Food Agric 29, 777-787

Hartley RD, Morrison III WH, Himmelsbach DS, Borneman WS (1990) Cross-linking of cell wall phenolic arabinoxylans in graminaceous plants. Phytochemistry (Oxf) 29 (12), 3705-3709

Helm RF, Ralph J (1991) Synthetic cell wall fragments related to lignin-phenolic acid-carbohydrates interactions. Poster abstract, International symposium on forage cell wall structure and digestibility, October 7-10 1991, Madison, USA

Hoden A, Barrière $Y$, Gallais A, Huguet L, Journet $M$, Mourguet A (1985) Le maïs brown midrib plante entière. 3. Utilisation sous forme d'ensilage par les vaches laitières. Bull Tech CRZV Theix INRA 60, 43-58

liyama K, Lam TBT, Stone BA (1990) Phenolic acid bridges between polysaccharides and lignin in wheat internodes. Phytochemisty (Oxf) 29 (3) 733-737

Inoue N, Kasuga S (1989) Agronomic traits and nutritive value of stover in brown midrib-3 maize hybrids. J Jpn Soc Grass/ Sci 35 (3), 220-227

Inoue N, Kasuga S (1990) Nutritive value and quality of brown midrib-3-maize silage. $J$ Jpn Soc Grass $/$ Sci 36 (3), 223-230

Ishii T, Tadakazu H, Thomas JR (1990) Feruloylated xyloglucan and $p$-coumaroyl arabinoxylan oligosaccharides from bamboo shoot cell-walls. Phytochemistry (Oxf) 29 (6), 1999-2003

Jorgenson LR (1931) Brown midrib in maize and its lignage relations. J Am Soc Agron 23, 549-557

Jung $H G$ (1989) Forage lignins and their effects on fiber digestibility. Agron J 81, 33-38

Kato $Y$, Nevins DJ (1985) Isolation and identification of $O$-(5-O-feruloyl- $\alpha$-L-arabinofuranosyl)-(1--->3-O B-D-xylopyranosyl-(-->4)-D-xylopyranose as a component of Zea shoot cell-walls. Carbohydr Res $137,139-150$

Keith EA, Colenbrander VF, Lechtenberg VL, Bauman LF (1979) Nutritional value of brown midrib corn silage for lactating dairy cows. J Dairy Sci 62, 788-792

Keith EA, Colenbrander VF, Perry TW, Bauman LF (1981) Performance of feedlot cattle fed brown midrib-three or normal corn silage with various levels of additional corn grain. J Anim Sci 52 (1), 8-13

Köhler R, Leuoth A, Jeroch H, Flachowsky G, Gebhardt $G$, Hielscher $H$, Kappel W (1989) Untersuchungen in Restflanzen verschiedener Maishybriden. Arch Anim Nutr, Berl 39 (1/2), 187-192

Köhler R, Jeroch H, Flachowsky G, Gebhardt G, Hielscher H, Kappel W (1990) Futtermittelkundliche Bewertung verschiedener Maisgenotypen. Arch Anim Nutr, Berl 40 (3), 267-274 
Kondo T, Hiroi T, Mizuno K, Kato T (1990) Cell-wall bound $p$-coumaric and ferulic acids in Italian ryegrass. Can J Plant Sci 71, 495-499

Kuc J, Nelson OE (1964) The abnormal lignins produced by the brown midrib mutants of maize. 1 . The brown midrib- 1 mutant. Arch Biochem Biophys 105, 103-113

Kuc J, Nelson OE, Flanagan P (1968) Degradation of abnormal lignins in the brown-mibrid mutants and double mutants of maize. Phytochemistry (Oxf) 7 , 1345-1346

Lapierre C (1992) Investigation structurale des lignines. Miscellaneous paper of the workshop "INRAAgrobio lignine".

Lapierre C, Tollier MT, Monties B (1988) Mise en évidence d'un nouveau type d'unité constitutive dans les lignines d'un mutant de maïs bm3. CR Acad Sci Paris, Ser III, 723-728

Lechtenberg VL, Muller LD, Bauman LF, Rhykerd CL, Barnes RF (1972) Laboratory and in vivo evaluation of inbred and F2 populations of brown-midrib mutants of Zea mays L. Agron J 64, 657-680

Lechtenberg BL, Colenbrander VF, Bauman LF, Rhykerd CL (1974) Effect of lignin on rate of in vitro cell wall and cellulose disappearance in corn. $J$ Anim Sci 39, 1165-1169

Lee MH, Brewbaker JL (1984) Effects of brown midrib-3 on yield and yield components of maize. Crop Sci 24, 105-108

Lewis NG, Yamamoto E (1990) Lignin: occurrence, biogenesis and biodegradation. Annu Rev Plant Physiol Plant Mol Biol 41, 455-496

Malterre C, Bertin G, Gallais A, Huguet L, Micol D (1985) Le maïs brown midrib plante entière. 2. Utilisation sous forme d'ensilage par les taurillons. Bull Tech CRZV Theix INRA 60, 43-58

Miku V, Komarova GE, Rotar Al (1980) Genetic variation in lignin content in maize. Doklady Vsesoyuznoi Ordena Lenina i Ordena Trudovogo Krasnogo Znameni Akademii Sel'slolhozyaïstvennykh Nauk Imeni VI Lenina 9, 9-10

Miller JA, Geadelmann JR (1983) Effect of the brown midrib-3 allele on early vigor and growth rate of maize. Crop Sci 23, 510-513

Miller JA, Geadelmann JL, Marten GC (1983) Effect of the brown midrib- 3 allele on maize silage quality and yield. Crop Sci 23, 493-496

Monties B (1989) Lignins. In: Methods in Plant Biochemistry (PM Dey and JB Harborne) 118-121

Morrison IM (1974) Structural investigations on the lignin-carbohydrate complexes of Lolium perenne. Biochem J 139, 197-204

Mueller-Harvey I, Hartley RD (1986) Linkage of $p$ coumaroyl and feruloyl groups to cell-wall polysaccharides of barley straw. Carbohydr Res 148, 71-85

Muller LD, Barnes FR, Bauman LF, Colenbrander VF (1971) Variation in lignin and other structural components of brown midrib mutant of maize. Crop Sci $11,413-415$
Muller LD, Lechtenberg VL, Bauman LF, Barnes RF, Rhykerd CL (1972) In vivo evaluation of a brown midrib mutant of Zea mays. J Anim Sci 35, 883-889

Nesticky M, Huska J (1985) Stalk strength in maize with brown midribs. In: Breeding of silage maize. Proc of the 13th Congress of the maize and Sorghum section of Eucarpia. Wageningen, The Netherlands 9-12 September 1985, 107-110

Neuffer MG, Jones L, Zuber MS (1968) The mutants of maize. Crop Sci Soc of America eds

Nishitani K, Nevins DJ (1987) Dissociation of ferulated arabinoxylan (FAX) from corn cell wall by a novel bacillus subtilis hydrolase. Plant physiol 83 (5), 106

Rook JA, Muller LD, Shank DB (1977) Intake and digestibility of brown midrib corn silage by lactating dairy cows. J Dairy Sci 60, 1894-1904

Scalbert A, Monties B, Lallemand JY, Guittet E, Rolando $C$ (1985) Ether linkage between phenolic acids and lignin fractions from wheat straw. Phytochemistry (Oxf) 24 (6), 1359-1362

Sheldrick RD (1979) The quality of brown midrib-3 mutant maize grown for forage under field conditions in southern England. Grass Forage Sci 34, 283-291

Van Soest PJ (1963) Use of detergents in the analysis of fibrous feeds. III. Preparation of fiber residues of low nitrogen content. J Ass Off Analyt Chem 46, 825-835

Van Soest PJ (1965) Use of detergents in the analysis of fibrous feeds. III. Study of effects of heating and drying on yield of fiber and lignin in forages. $J$ Ass Off Analyt Chem 48, 785-790

Van Soest PJ (1967) Development of a comprehensive system of feed analyses and its application to forages. J Anim Sci 26, 119-128

Sommerfeldt JL, Shingoethe DJ, Muller LD (1979) Brown midrib corn silage for lactating dairy cows. $J$ Dairy Sci 62, 1611-1618

Stallings CC, Donaldson BM, Thomas JW, Rossman EC (1982) In vivo evaluation of brown-midrib corn silage by sheep and lactating dairy cows. J Dairy Sci 65, 1945-1949

Tilley JMA, Terry RA (1963) A two-stage technique for the in vitro digestion of forage crops. J Brit Grass! Soc 18, 104-111

Thorstensson EMG, Buxton DR, Cherney JG (1992) Apparent inhibition to digestion by lignin in normal and brown midrib stems. J Sci Food Agric 59, 183-188

Weller RF, Phipps RH, Griffith ES (1984) The nutritive value of normal and brown midrib-3 maize. J Agric Sci 103, 223-227

Weller RF, Phipps RH, Cooper A (1985) The effect of the brown midrib-3 gene on the maturity and yield of forage maize. Grass Forage Sci 40, 335-339

Weller RF, Phipps RH (1986) The feeding value of normal and brown midrib-3 maize silage. J Agric Sci 106, 31-35

Zuber MS, Colbert TR, Bauman LF (1977) Effect of brown-midrib-3 mutant in maize (Zea mays $\mathrm{L}$ ) on stalk strength. Z Planzenzüchtg 79, 310-314 